\title{
FBG (FIBER BRAGG GRATING) UNTUK DWDM (DENSE WAVELENGTH DIVISION MULTIPLEXING)
}

\author{
Diana Murianti*), Teguh Prakoso, dan Aghus Sofwan \\ Departemen Teknik Elektro, Universitas Diponegoro \\ Jl. Prof. Sudharto, SH, Kampus UNDIP Tembalang, Semarang 50275, Indonesia \\ ${ }^{*}$ E-mail: dmurianti25@gmail.com
}

\begin{abstract}
Abstrak
Pada era modern ini, tuntutan kebutuhan masyarakat akan layanan komunikasi semakin meningkat. Kebutuhan tersebut meliputi layanan video, suara dan data. Penambahan kapasitas ini dapat dilakukan dengan menggunakan teknologi Dense Wavelength Division Multiplexing (DWDM). Salah satu perangkat yang digunakan teknologi DWDM yaitu Optical Add/Drop Multiplexer (OADM). OADM digunakan untuk melewatkan sinyal dan melakukan fungsi add dan drop. Salah satu perangkat yang mendukung untuk membantu kerja dari OADM adalah Fiber Bragg Grating (FBG). Tujuan pembuatan Penelitian ini adalah mendapatkan parameter desain FBG yang terbaik untuk jaringan DWDM berdasarkan nilai crosstalk, $Q$ factor, dan Bit Error Rate (BER) guna memperoleh konfigurasi jaringan DWDM yang optimal. Pada Penelitian ini dilakukan dengan menggunakan dua software. Pertama, menggunakan software Optisystem 7 untuk memodelkan sistem. Kedua, menggunakan software Optigrating 4.2.3 untuk verifikasi FBG. Parameter desain FBG yang terbaik yaitu dengan panjang grating 18600 um. Berdasarkan hasil ko-simulasi, nilai rata-rata BER hasil simulasi menggunakan FBG Optisystem adalah $1,19 \times 10^{-15}$, sedangkan saat menggunakan FBG Optigrating adalah $4,15 \times 10^{-15}$. Nilai rata - rata $Q$ Factor hasil simulasi menggunakan FBG Optisystem adalah 8,43, sedangkan saat menggunakan FBG Optigrating adalah 8,18. Nilai rata - rata crosstalk hasil simulasi menggunakan FBG Optisystem adalah $-39,63 \mathrm{~dB}$, sedangkan saat menggunakan FBG Optigrating adalah -39,72 dB.
\end{abstract}

Kata Kunci : FBG uniform, OADM, DWDM

\begin{abstract}
In this modern era, the demands of society's need for communication services are increasing. These requirements include video, voice and data services. The addition of this capacity can be done by Dense Wavelength Division Multiplexing technology. One of the devices used DWDM technology is the Optical Add / Drop Multiplexer (OADM). OADM is used to pass signals and to perform add and drop functions. One of the supporting tools to assist the work of OADM is Fiber Bragg Grating (FBG). The purpose of this Research is to get the best FBG design parameters for DWDM network based on Bit Error Rate (BER), Q factor, and crosstalk values to obtain optimal DWDM network configuration. This Research uses two software. First, Optisystem 7 software is to model the system. Second, Optigrating 4.2.3 software for FBG verification. The best FBG design parameters are the 18600 um grating length. Based on the co-simulation result, the mean value of BER simulation result using FBG Optisystem of 1.19x10-15, while the moment using FBG Optigrating of 4.15x10-15. The mean value of Q Factor simulation result using FBG Optisystem of 8.43 , while the moment using FBG Optigrating of 8.18 . The average value of crosstalk simulated using FBG Optisystem of $-39.63 \mathrm{~dB}$, while the moment using FBG Optigrating of $-39.72 \mathrm{~dB}$.
\end{abstract}

Keywords: FBG uniform, OADM, DWDM

\section{Pendahuluan}

Pada era modern ini, teknologi informasi dan komunikasi berkembang sangat pesat. Hal ini dikarenakan tuntutan kebutuhan masyarakat akan layanan komunikasi yang semakin meningkat. Masyarakat jaman sekarang tidak hanya membutuhkan layanan suara saja seperti jaman dahulu, namun juga membutuhkan layanan video dan data. Selain itu, layanan - layanan tersebut diinginkan bersifat praktis, mudah, dan efisien. Teknologi serat optik menjadi solusi karena mampu mentransmisikan informasi pada kecepatan giga bit per second (Gbps) bahkan mencapai tera bit per second (Tbps) sehingga dapat memberikan fleksibilitas yang tinggi dalam memenuhi kebutuhan kapasitas transmisi pada jaringan. Penambahan kapasitas ini dapat dilakukan dengan menumpangkan beberapa panjang gelombang ke dalam satu serat optik. Teknologi ini disebut dengan Dense Wavelength Division Multiplexing (DWDM). Skema sederhana sistem DWDM ditunjukkan pada Gambar 1. 
Di antara titik multipleksing dan demultipleksing dalam sistem DWDM merupakan daerah dimana berbagai macam panjang gelombang berada, pada beberapa titik sepanjang span ini sering diinginkan untuk menghilangkan atau menambah dengan satu atau lebih panjang gelombang. Optical Add/Drop Multiplexer (OADM) inilah yang digunakan untuk melewatkan sinyal dan melakukan fungsi add dan drop. Salah satu perangkat yang mendukung untuk membantu kerja dari OADM adalah Fiber Bragg Gratring (FBG). FBG merupakan salah satu jenis filter yang indeks biasnya berubah secara periodik, sehingga FBG dapat berfungsi sebagai refleksi dan transmisi,[1].

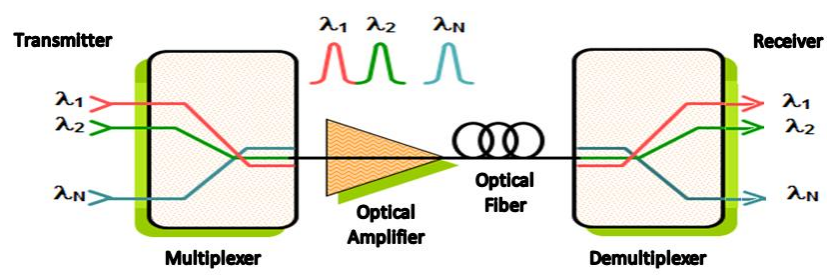

Gambar 1. Skema Sederhana Sustem DWDM

Dari beberapa referensi, telah dilakukan pembahasan mengenai perbandingan kinerja jaringan sistem komunikasi serat optik berdasarkan modulator optik,[2] analisa kinerja jaringan $D W D M$ berdasarkan tipe serat optik,[3] simulasi dan analisa akibat adanya tekanan terhadap FBG sebagai filter optik pada DWDM,[4] simulasi dan analisa $O A D M$ menggunakan $F B G$ berteknologi $W D M$,[5] analisa OADM menggunakan FBG pada DWDM berdasarkan persamaan matematis,[6] dan simulasi OADM untuk Radio over Fiver (Rof),[7].

Meskipun dapat dijumpai penelitian mengenai OADM yang diaplikasikan pada sistem DWDM, namun belum dijumpai penelitian yang membandingkan antara empat konfigurasi OADM dengan FBG uniform sebagai dropper dan diaplikasikan pada sistem DWDM yang telah ditentukan spesifikasinya. Tujuan Penelitian ini adalah mendapatkan parameter desain FBG yang terbaik untuk jaringan DWDM berdasarkan nilai crosstalk, $Q$ factor, dan Bit Error Rate (BER) guna memperoleh konfigurasi jaringan DWDM yang optimal.

\section{Metode}

Pada Penelitian memiliki 2 tahap dalam melakukan simulasi. Pertama, menggunakan software Optisystem 7, dimana software ini dapat digunakan untuk memodelkan sistem komunikasi optik yang bersifat nyata dan juga dapat digunakan untuk perancangan jaringan DWDM karena Optisystem merupakan software yang memungkinkan untuk mendesain, menguji dan mensimulasikan jaringan optik. Optisystem dilengkapi dengan GUI (Graphical User Interface) antara lain project layout, component list, model komponen dan tampilan grafik. Kedua, menggunakan software Optigrating 4.2.3, dimana software ini dapat digunakan untuk memodelkan perangkat serat optik dan terpadu yang menggabungkan kisi-kisi optik. Biasanya Optigrating digunakan perancang untuk mencari informasi yang dibutuhkan untuk pengujian dan mengoptimalkan desain kisi. Untuk itu, Optigrating dalam Penelitian ini digunakan untuk verifikasi FBG uniform yang bertujuan untuk mencocokkan apakah benar FBG dapat difungsikan sebagai dropper di dalam konfigurasi OADM yang diaplikasikan dalam sistem DWDM. Gambar 2 menunjukkan diagram alir Penelitian ini. Diagram alir ini meliputi dari mulai pencarian spesifikasi filter FBG sampai analisa.

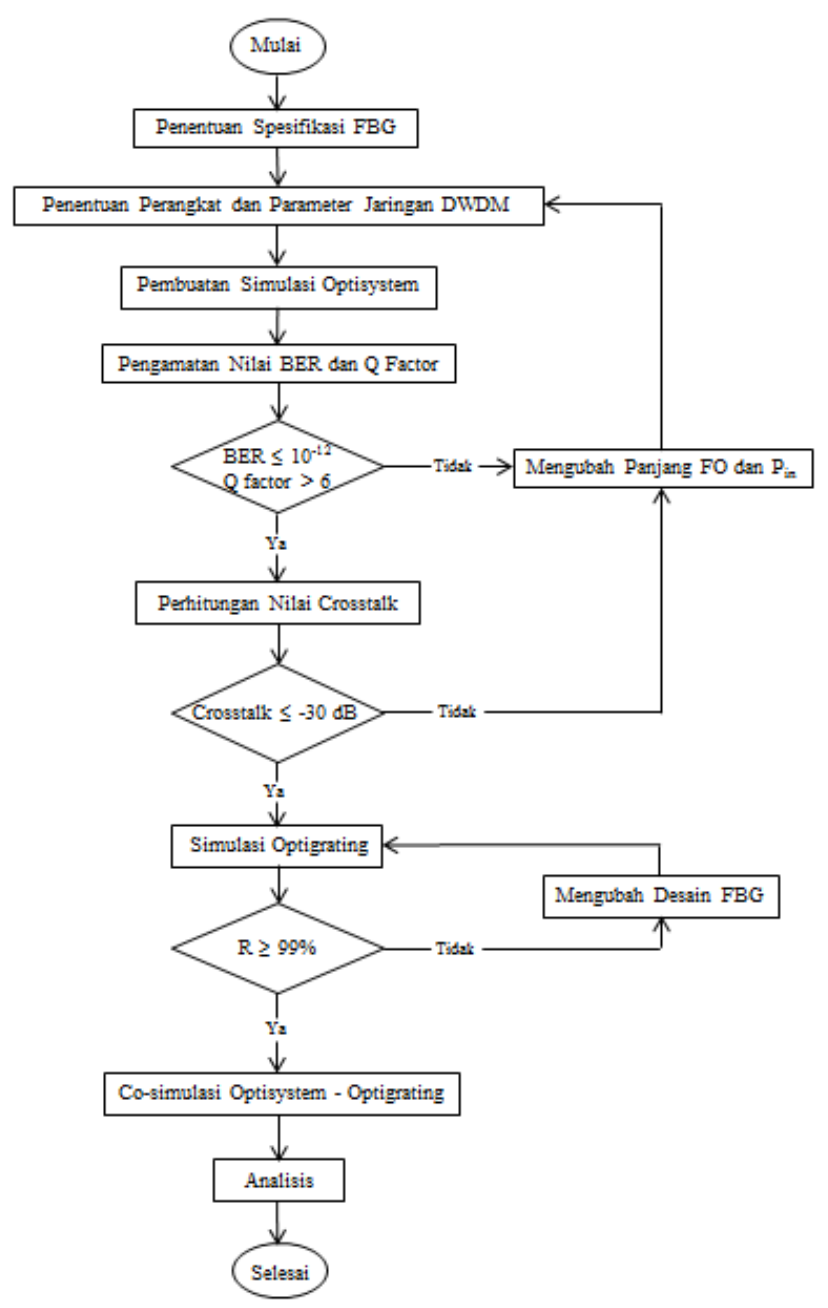

Gambar 2. Diagram Alir Penelitian

Skenario yang digunakan dalam Penelitian ini diambil dari parameter sistem DWDM. Parameter tersebut terdiri dari jumlah wavelength, spasi kanal, rentang frekuensi, dan empat konfigurasi OADM. Tabel 1 menunjukkan skenario sistem yang disimulasikan.

Gambar 3 menunjukkan skema Penelitian ini. Skema terdiri dari spesifikasi DWDM yang diinginkan, 
performance metic yang dilihat, tahap pengerjaan Penelitian, spesifikasi dan parameter FBG yang digunakan, software yang digunakan, serta variabel yang diubah-ubah.

Tabel 1. Skenario sistem yang disimulasikan beserta pengelompokkannya

\begin{tabular}{|c|c|c|c|c|}
\hline $\begin{array}{c}\text { Kelompok } \\
\text { Skenario }\end{array}$ & $\begin{array}{c}\text { Konfigrasi OADM } \\
\mathrm{Ke}-\end{array}$ & $\begin{array}{c}\text { Jumlah } \\
\text { Wavelength }\end{array}$ & Spasi Kanal & $\begin{array}{c}\text { Rentang } \\
\text { Frekuensi }\end{array}$ \\
\hline 1 & $\begin{array}{l}1 \\
2 \\
3 \\
4\end{array}$ & 16 & \multirow{2}{*}{$50 \mathrm{GHz}$} & \multirow{4}{*}{ C Band } \\
\hline II & $\begin{array}{l}1 \\
2 \\
3 \\
4\end{array}$ & 32 & & \\
\hline III & $\begin{array}{l}1 \\
2 \\
3 \\
4\end{array}$ & 16 & \multirow{2}{*}{$100 \mathrm{GHz}$} & \\
\hline IV & $\begin{array}{l}1 \\
2 \\
3 \\
4\end{array}$ & 32 & & \\
\hline V & $\begin{array}{l}1 \\
2 \\
3 \\
4\end{array}$ & 16 & \multirow{2}{*}{$50 \mathrm{GHz}$} & \multirow{4}{*}{ L Band } \\
\hline VI & $\begin{array}{l}1 \\
2 \\
3 \\
4\end{array}$ & 32 & & \\
\hline VII & $\begin{array}{l}1 \\
2 \\
3 \\
4\end{array}$ & 16 & \multirow{2}{*}{$100 \mathrm{GHz}$} & \\
\hline VIII & $\begin{array}{l}1 \\
2 \\
3 \\
4 \\
\end{array}$ & 32 & & \\
\hline
\end{tabular}

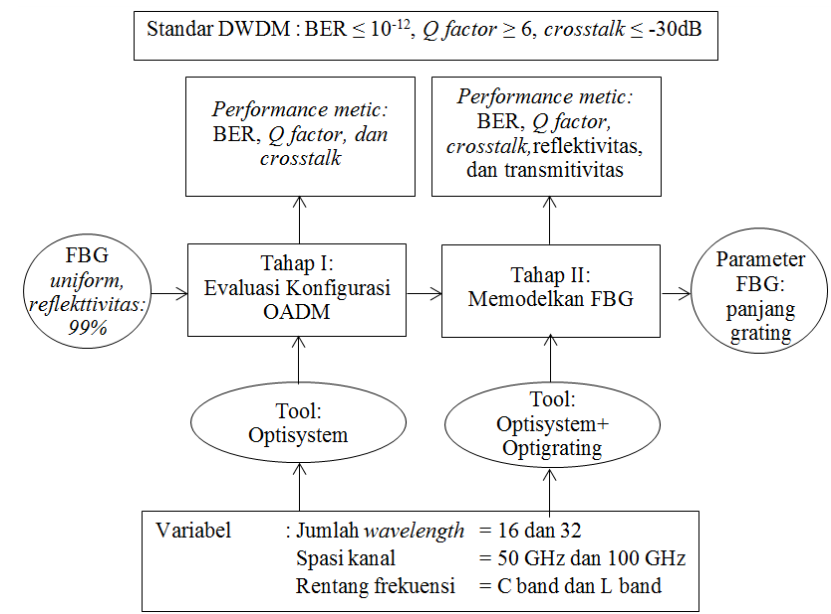

\subsection{Spesifikasi FBG}

Prinsip kerja FBG yaitu ketika cahaya melalui daerah yang secara periodik berubah-ubah dari indeks refraktif tinggi dan rendah. FBG yang digunakan dalam Penelitian ini adalah FBG jenis uniform, dimana filter ini mempunyai kisi yang seragam, sehingga $\Lambda$ periode bragg grating-nya adalah konstan. Adanya grating tersebut di dalam fiber menyebabkan fiber bragg grating merefleksikan panjang gelombang cahaya yang hanya memenuhi kondisi bragg dan mentransmisikan semua panjang gelombang yang lain. Input Transmisi Refleksi Bragg grating tersebut dibuat di dalam fiber optik itu sendiri tanpa merubah bentuk fiber dan menjadikannya komponen di dalam fiber. Untuk lebih jelasnya dapat dilihat pada Gambar 4. Persamaan (1) menunjukkan reflektivitas gelombang cahaya yang memenuhi kondisi bragg:

$R_{\max }=\tanh ^{2}(k . L)$ dimana,

$$
\begin{aligned}
& \mathrm{k}=\text { koefisien kopling } \\
& \mathrm{L}=\text { panjang grating }
\end{aligned}
$$

Pada Penelitian ini, $\lambda_{\text {Bragg }}$ yang digunakan yaitu:

1. Untuk C Band dengan spasi kanal $100 \mathrm{GHz}$ adalah $1555,75 \mathrm{~nm}$

2. Untuk $\mathrm{C}$ Band dengan spasi kanal $50 \mathrm{GHz}$ adalah $1556,15 \mathrm{~nm}$

3. Untuk L Band dengan spasi kanal $100 \mathrm{GHz}$ adalah $1597,19 \mathrm{~nm}$

4. Untuk L Band dengan spasi kanal $50 \mathrm{GHz}$ adalah $1597,62 \mathrm{~nm}$

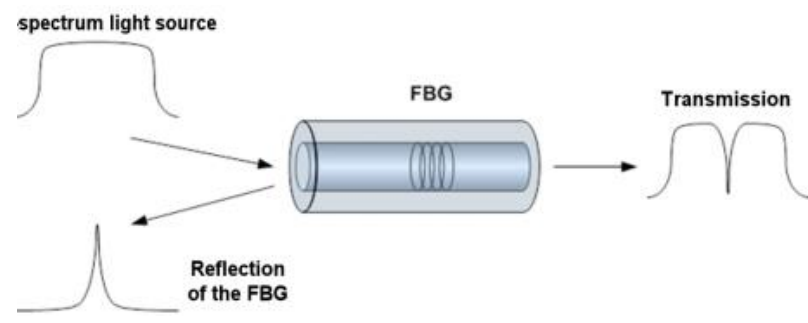

Gambar 4. Fiber Bragg Grating

Ada berbagai cara untuk mendapatkan nilai refelektivitas yang diinginkan, salah satunya yang digunakan dalam Penelitian ini yaitu dengan menambah nilai panjang grating. Struktur Fiber Bragg Grating ditunjukkan oleh Gambar 5. 


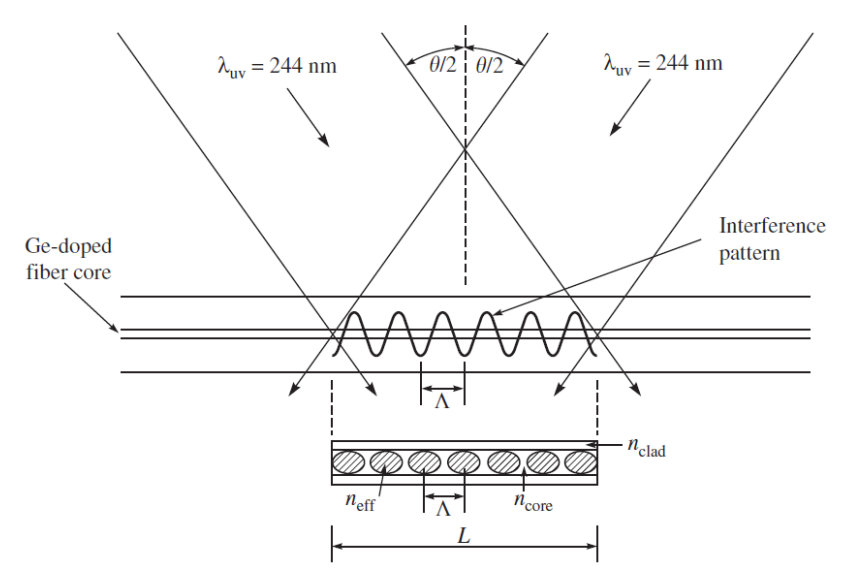

Gambar 5. Struktur FBG

Tabel 2 menunjukkan spesifikasi FBG yang digunakan dalam simulasi jaringan DWDM dengan Optisystem.

Tabel 2. Spesifikasi FBG Optisystem

\begin{tabular}{ll}
\hline \multicolumn{1}{c}{ Parameter } & \multicolumn{1}{c}{ Spesifikasi } \\
\hline Jenis & Uniform \\
Frekuensi & 1555,$75 ; 1556,15 ;$ \\
& 1597,$19 ; 1597,62$ \\
Refelektivitas & $99 \%$ \\
\hline
\end{tabular}

Tabel 3 menunjukkan spesifikasi FBG yang digunakan dalam simulasi Optigrating.

Tabel 3. Spesifikasi FBG Optigrating

\begin{tabular}{ll}
\hline \multicolumn{1}{c}{ Parameter } & \multicolumn{1}{c}{ Spesifikasi } \\
\hline Frekuensi & 1555,$75 ; 1556,15 ;$ \\
& 1597,$19 ; 1597,62$ \\
Grating Shape & Sine \\
Period Chirp & No chirp \\
Apodization & Uniform \\
Panjang Grating & 18600 um \\
Ind. Mod. & 0,0001 \\
Number of Segment & 1 \\
Periode & 0,5345 \\
\hline
\end{tabular}

Gambar 6 menunjukkan grafik transmitivitas dan reflektivitas FBG dalam software Optigrating dengan spesifikasi yang ditunjukkan oleh Tabel 3. Pada Penelitian ini digunakan reflektivitas $99 \%$.

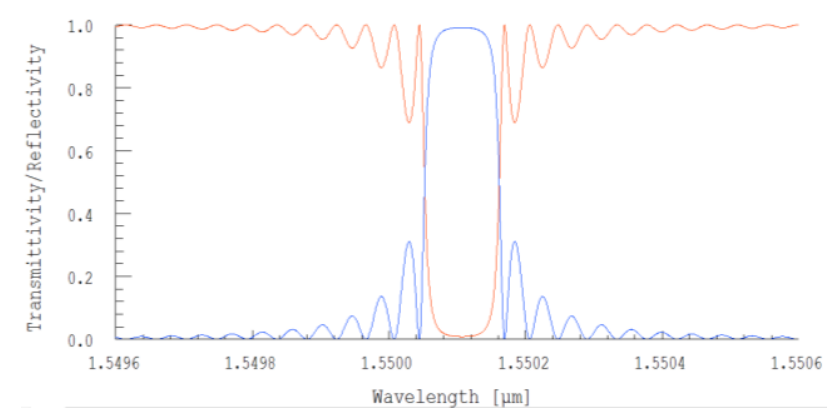

Gambar 6. Reflektivitas FBG Optigrating
Grafik berwarna merah merupakan grafik transmitivitas dan grafik berwarna biru merupakan grafik reflektivitas. Garik reflektivitas terlihat mendekati nilai 1. Namun apabila dilakukan zoom in terlihat dengan jelas nilai reflektivitas bernilai $99 \%$.

\subsection{Desain Sistem DWDM}

Desain sistem DWDM ditunjukkan pada Gambar 7. Ada 3 subsystem.. Subsystem digunakan untuk memberikan kesan rapi dalam desain karena subsystem dapat mengelompokkan komponen - komponen menjadi 1 yang bila tidak dikelompokkan akan terlihat seperti desain yang kompleks dan susah dimengerti.

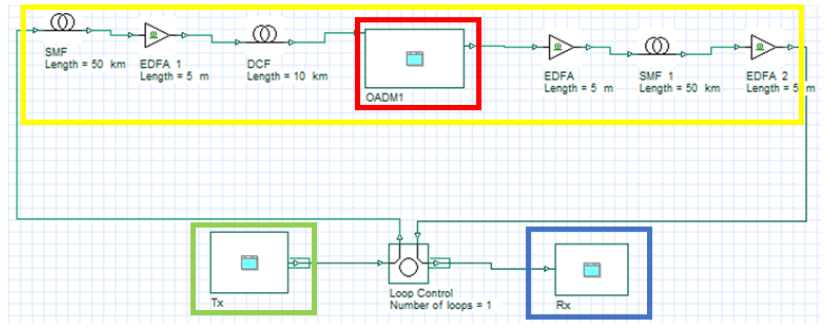

\section{Gambar 7. Desain Sistem DWDM}

Subsystem yang berada dalam kotak warna hijau menunjukkan transmitter. Subsystem yang berada dalam kotak warna biru menunjukkan receiver. Subsystem yang berada dalam kotak warna merah menunjukkan OADM. Desain pada Gambar 7 hanya salah satu dari skenario yang digunakan. Gambar 8 memperlihatkan 4 konfigurasi OADM,[8].

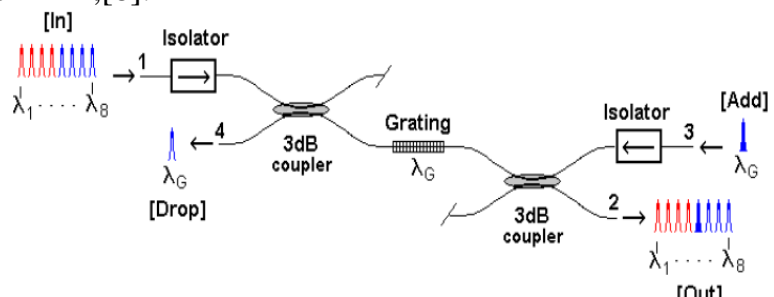

(a)

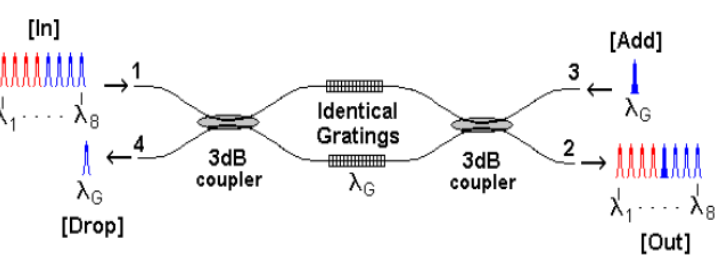

(b)

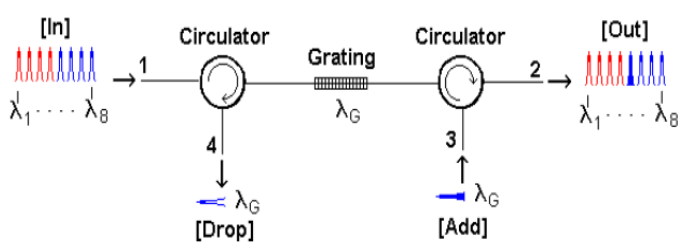

(c)

Gambar 8. OADM (a) Konfigurasi ke-1 (b) Konfigurasi ke2, dan (c) Konfigurasi ke-3 


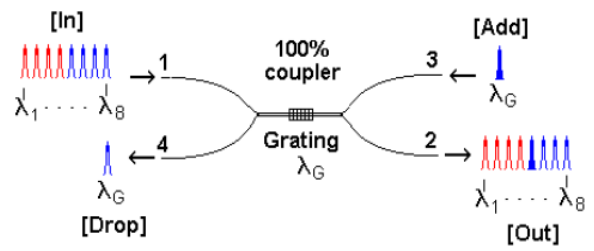

(d)

\section{Gambar 8. (Lanjutan) OADM (d) Konfigurasi ke-4}

\section{Hasil dan Analisa}

Berdasarkan 32 skenario yang telah dilakukan dan dibandingkan berdasarkan nilai BER dan $Q$ Factor, didapatkan konfigurasi simulasi DWDM terbaik yang memenuhi standar nilai BER dan $Q$ Factor untuk DWDM yaitu masing - masing maksimal $10^{-12}$ dan minimal 6 . Desain terbaik adalah konfigurasi OADM ke-2, jumlah wavelength 16, rentang frekuensi $\mathrm{C}$ band dan spasi kanal $100 \mathrm{GHz}$. Tabel 4 menunjukkan nilai BER dan $Q$ Factor dari konfigurasi simulasi DWDM terbaik.

Tabel 4. Nilai BER dan $Q$ factor dari konfigurasi simulasi DWDM terbaik

\begin{tabular}{cccccc}
\hline $\begin{array}{c}\text { Channel } \\
\text { ke- }\end{array}$ & BER & Q factor & $\begin{array}{c}\text { Channel } \\
\text { ke- }\end{array}$ & BER & Q factor \\
\hline 1 & $7,59 \mathrm{E}-26$ & 10,43 & 9 & $4.59 \mathrm{E}-22$ & 9,58 \\
2 & $5,71 \mathrm{E}-15$ & 7,71 & 10 & $3,06 \mathrm{E}-19$ & 8,88 \\
3 & $4,37 \mathrm{E}-17$ & 8,31 & 11 & $7,12 \mathrm{E}-15$ & 7,68 \\
4 & $2,00 \mathrm{E}-17$ & 8,41 & 12 & $7,70 \mathrm{E}-17$ & 8,24 \\
5 & $1,23 \mathrm{E}-15$ & 7,91 & 13 & $2,23 \mathrm{E}-16$ & 8,11 \\
6 & $2,14 \mathrm{E}-15$ & 7,84 & 14 & $2,36 \mathrm{E}-18$ & 8,65 \\
7 & $3,01 \mathrm{E}-16$ & 8,08 & 15 & $7,48 \mathrm{E}-19$ & 8,78 \\
8 & $8,65 \mathrm{E}-16$ & 7,95 & 16 & $4,65 \mathrm{E}-17$ & 8,29 \\
\hline
\end{tabular}

Konfigurasi OADM ke-2 menjadi konfigurasi simulasi DWDM terbaik karena mempunyai performa lebih bagus dibandingkan OADM ke-1, OADM ke-3, dan OADM ke4. Hal ini dikarenakan pada OADM ke-2 menggunakan 2 FBG uniform sehingga reflektivitas lebih bagus dibandingkan konfigurasi lain yang hanya menggunakan 1 FBG. Ketika reflektivitas bagus maka wavelength yang diteruskan akan memiliki daya yang kecil sehingga ketika wavelength dari adder masuk, maka dayanya tidak banyak berkurang karna bercampur dengan sisa daya dari wavelength yang diteruskan

Konfigurasi simulasi DWDM terbaik memiliki jumlah wavelength 16 . Perbandingan skenario berdasarkan jumlah wavelength menunjukkan bahwa semakin banyak jumlah wavelength maka performansi semakin buruk. Hal ini dikarenakan semakin banyak jumlah wavelength maka secara keseluruhan bit yang ditransmisikan semakin banyak pula, sehingga kemungkinan terjadinya crosstalk semakin besar.
Rentang frekuensi C band mempunyai performa lebih bagus daripada rentang frekuensi L. Hal ini dikarenakan pada rentang frekensi $\mathrm{C}$, mempunyai nilai pelemahan (attenuasi) yang lebih kecil dibandingan pada rentang frekuensi L, sehingga hal ini mempengaruhi performansi sistem.

Spasi kanal $100 \mathrm{GHz}$ memiliki performa lebih bagus dibandinkan spasi kanal $50 \mathrm{GHz}$. Hal ini dikarenakan semakin besar spasi kanal maka kerapatan antar wavelength semakin lebar, sehingga kemungkinan interferensi antar wavelength kecil. Spasi kanal $50 \mathrm{GHz}$ sama dengan 0,4 nm dan untuk spasi kanal $100 \mathrm{GHz}$ sama dengan $0,8 \mathrm{~nm}$, sehingga $100 \mathrm{GHz}$ memiliki performansi lebih baik daripada penggunaan spasi kanal $50 \mathrm{GHz}$.

Setelah ditemukan konfigurasi simulasi DWDM terbaik berdasarkan nilai BER dan $Q$ factor, langkah selanjutnya adalah menghitung nilai crosstalk dengan persamaan (2) dan verifikasi FBG,[9].

Crosstalk $=10 \log \frac{\text { Pout }}{\text { P'out }}$

dimana,

$\mathrm{P}^{\prime}{ }_{\text {out }}=$ daya keluaran yang diterima dengan melibatkan crosstalk (Watt)

$\mathrm{P}_{\mathrm{ou}}=$ daya keluaran yang diterima tanpa melibatkan crosstalk (Watt)

Verifikasi FBG dilakukan dengan cara memanggil file desain FBG Optigrating melalui Optiwave Software Tools yang tersedia di software Optisystem. Kemudian dilakukan perbandingan hasil nilai BER, $Q$ Factor, dan crosstalk yang dihasilkan antara simulasi konfigurasi simulasi DWDM terbaik menggunakan FBG Optisystem dan FBG Optigrating. Standart nilai crosstalk untuk DWDM yaitu maksimal -30dB. Gambar 9 menunjukkan grafik perbandingan nilai BER. Gambar 10 menunjukkan grafik perbandingan nilai $Q$ factor. Gambar 11 menunjukkan grafik perbandingan nilai crosstalk,[10].

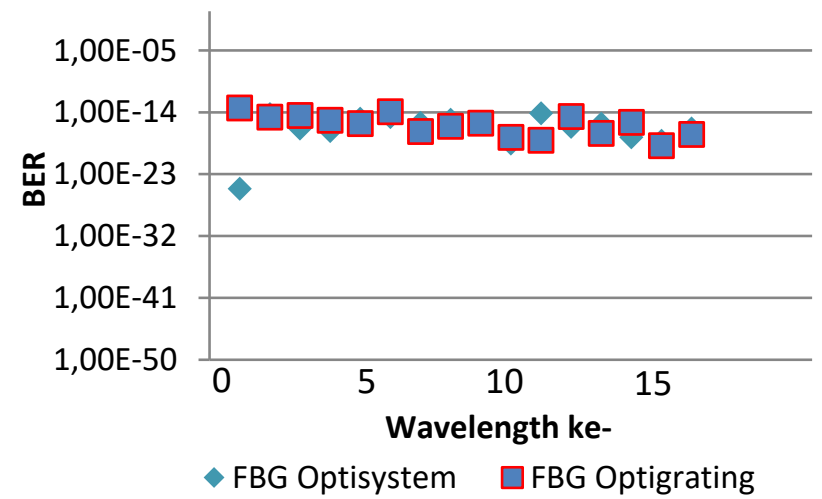

Gambar 9. Perbandingan BER

Perbandingan antara nilai BER saat menggunakan FBG Opstisystem dan FBG Optigrating terdapat perbedaan. 
Perbedaan terjauh berada pada wavelength pertama yaitu saat menggunakan FBG Optisystem bernilai 7,59x10-26, saat menggunakan FBG Optigrating bernilai 4,46×10-14. Perbedaan terdekat berada pada wavelength kedua yaitu saat menggunakan FBG Optisystem bernilai 5,71 $\times 10^{-15}$,

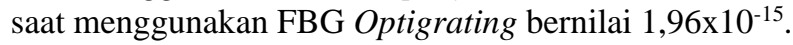
Gambar 10 menunjukkan grafik perbandingan nilai $Q$ factor antara menggunakan FBG Optisystem dan FBG Optigrating.

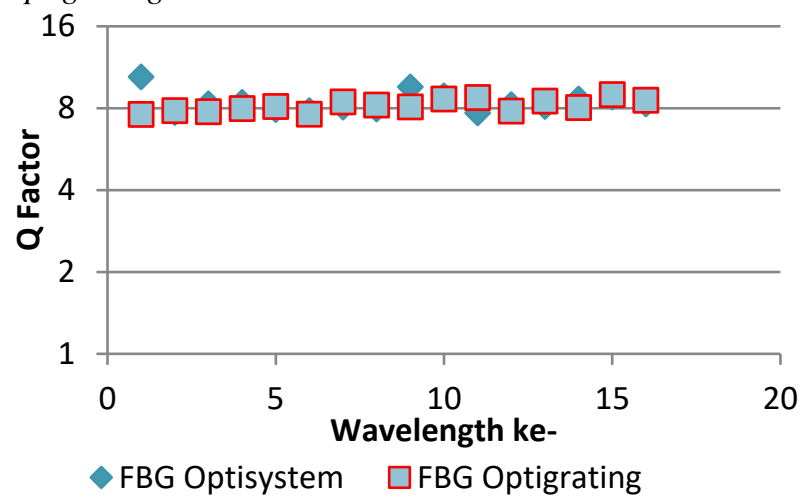

Gambar 10. Perbandingan $Q$ Factor

Perbandingan antara nilai $Q$ Factor saat menggunakan FBG Opstisystem dan FBG Optigrating terdapat perbedaan. Perbedaan terjauh berada pada wavelength pertama yaitu mempunyai selisih 2,84 . Perbedaan terdekat berada pada wavelength kedua yaitu mempunyai selisih 0,13 . Gambar 11 menunjukkan grafik perbandingan nilai crosstalk antara menggunakan FBG Optisystem dan FBG Optigrating.

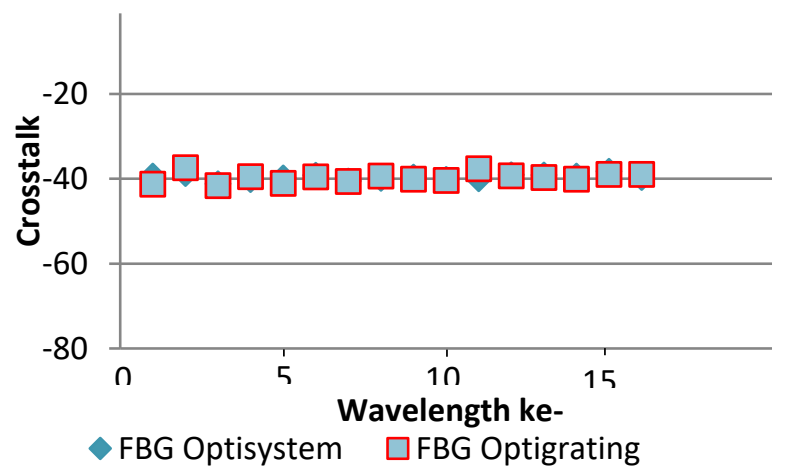

\section{Gambar 11. Perbandingan Crosstalk}

Perbandingan antara nilai crosstalk saat menggunakan FBG Opstisystem dan FBG Optigrating terdapat perbedaan. Perbedaan terjauh berada pada wavelength pertama yaitu mempunyai selisih 1,906. Perbedaan terdekat berada pada wavelength ke 7 yaitu mempunyai selisih 0,116 .

Perbedaan-perbedaan yang terjadi dikarenakan parameter-parameter FBG antara FBG Opstisystem dan FBG Optigrating tidak sama persis sehingga mengakibatkan perbedaan. Namun di samping perbedaan-perbedaan yang terjadi, secara fungsional untuk verifikasi FBG sudah memenuhi. Hal ini dibuktikan dengan layaknya nilai BER dan $Q$ factor yang berarti FBG dapat berfungsi sebagai dropper dalam OADM.

\section{Kesimpulan}

Berdasarkan nilai BER, $Q$ factor, dan crosstalk, desain FBG paling sesuai diaplikasikan pada jaringan DWDM dengan jumlah wavelength 16, kanal spasi $100 \mathrm{GHz}$, rentang frekuensi $\mathrm{C}$, dan konfiguasi OADM kedua. Parameter desain FBG yang terbaik yaitu dengan panjang grating $18600 \mathrm{um}$. Berdasarkan hasil ko-simulasi, nilai rata-rata BER (Bit Error Rate) hasil simulasi

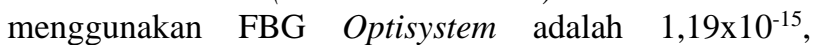
sedangkan saat menggunakan FBG Optigrating adalah $4,15 \times 10^{-15}$. Nilai rata-rata $Q$ Factor hasil simulasi menggunakan FBG Optisystem adalah 8,43, sedangkan saat menggunakan FBG Optigrating adalah 8,18 . Nilai rata-rata crosstalk hasil simulasi menggunakan FBG Optisystem adalah $-39,63 \mathrm{~dB}$, sedangkan saat menggunakan FBG Optigrating adalah -39,72 dB.

\section{Referensi}

[1]. Erdogan, Turan. 1997. "Fiber Grating Spectra". IEEE Journal of Lightwave Technology, Vol. 15, No. 8. Hlm.1277-1294.

[2]. Angesti, Wildand. 2015 "Simulasi Kinerja Modulator Optik Tipe Mach-Zehnder Berdasarkan Ragam Format Modulasi”. Transmisi, 17, (1), 2015, e-ISSN 2407-6422.

[3]. Rodhiah, Hana' Ad'ha. 2014. “Analisis Kinerja Jaringan Dwdm Berdasarkan Perbedaan Tipe Serat Optik Menggunakan Cisco Transport Plannern Release 9.2“. Transient, Vol.3, No.3, ISSN: 2302-9927.

[4]. Fachryto, Tamas. 2014. "Analisis Dan Simulasi Fiber Bragg Grating Sebagai Filter Optik Pada Dense Wavelength Division Multiplexing (DWDM)". Fakultas teknik Elektro, Universitas Telkom.

[5]. Permatasari, Yuliana. 2015 "Simulasi dan Analisis Penerapan OADM menggunakan FBG pada Ling Long Haul". e-Proceeding of Engineering, Vol.2, No.2 Agustus 2015. Hlm.2354-2361.

[6]. Widasari, Edita Rosana. 2013. "Analisis Penerapan Optical Add-Drop Multiplexer (Oadm) Menggunakan Fiber Bragg Grating (Fbg) Pada Teknik Dense Wavelength Division Multiplexing (DWDM)". Jurusan Teknik Elektro, Fakultas Teknik, Universitas Brawijaya. Hlm.1-6.

[7]. Kumar, S. Sily dan Keerthana P. 2015. "Simulation of RoF Using Wavelength Selective OADM “. International Journal of Research Studies in Science, Engineering and Technology Volume 2, Issue 9. Hlm.1622.

[8]. Alegria Carlos. 2002. Introduction to Add-Drop Multiplexer. Amsterdam.

[9]. Monroy, Idelfonso Tafur. 2002. Crosstalk in WDM Communication Network. New York: Kluwer Academic Publishers.

[10]. Keiser, Gerd. 2003. Optical Fiber Communication. New York: The McGraw-Hill Companie. 